\title{
Natural Product Triterpenoids and Their Semi-Synthetic Derivatives with Potential Anticancer Activity*
}

Authors

Yulin Ren, A. Douglas Kinghorn

\section{Affiliation}

Division of Medicinal Chemistry and Pharmacognosy, College of Pharmacy, The Ohio State University, Columbus, Ohio, United States

\section{Key words}

natural products, triterpenoids, antitumor activity, synthetic derivatives, structure-activity relationships, mechanisms of anticancer activity

received November 30, 2018

revised December 31, 2018

accepted January 5, 2019

Bibliography

DOI https://doi.org/10.1055/a-0832-2383

Published online January 18, 2019 | Planta Med 2019; 85:

802-814 @ Georg Thieme Verlag KG Stuttgart · New York ISSN 0032-0943

Correspondence

Prof. A. Douglas Kinghorn

Division of Medicinal Chemistry and Pharmacognosy,

College of Pharmacy, The Ohio State University

500 West 12th Avenue, Columbus, Ohio 43210, United States

Phone: + 161424780 94, Fax: + 16142478642

kinghorn.4@osu.edu

\begin{abstract}
Triterpenoids are distributed widely in higher plants and are of interest because of their structural diversity and broad range of bioactivities. In particular, there is a very large literature on the propensity of a variety of triterpenoids to act as potential anticancer agents. In the present review, the anticancer potential is summarized for naturally occurring triterpenoids and their semi-synthetic derivatives, including examples of lupane-, oleanane-, ursane-, and cucurbitane-type pentacyclic triterpenoids, along with dammarane-type tetracyclic triterpenes including ginsenosides and their sapogenins and dichapetalins, which have been characterized as antitumor leads from higher plants. Preliminary structure-activity relationships and reported mechanisms of the antineoplastic-related activity are included. Prior studies for triterpenoids of plant origin are supportive of additional work being conducted on the more detailed biological and mechanistic evaluation for the progression of this type of natural products as possible cancer chemotherapeutic agents.
\end{abstract}

* Dedicated to Professor Dr. Cosimo Pizza in recognition of his important contributions to natural product research on the occasion of his 70th birthday in 2019

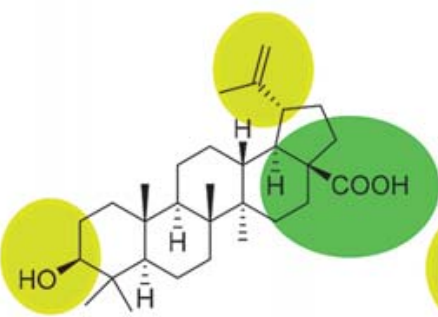

(+)-betulinic acid (1)

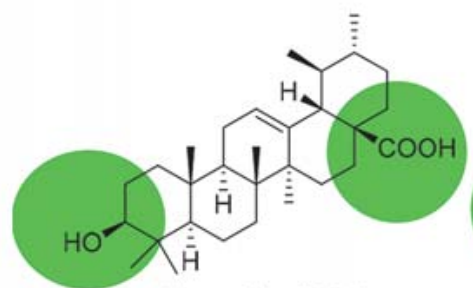

(+)-ursolic acid (11)
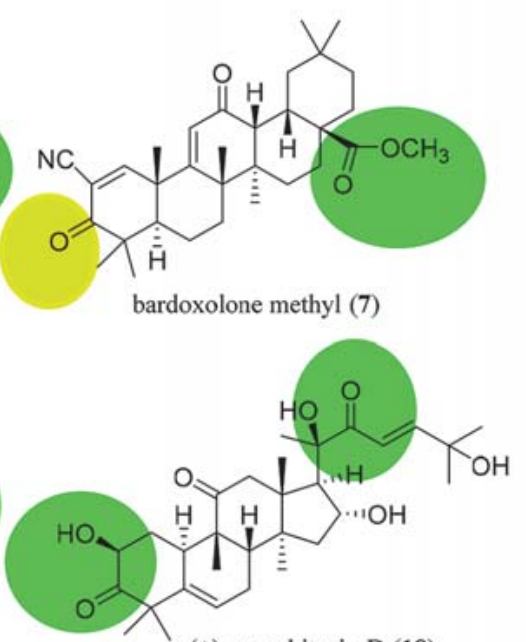

(+)-cucurbitacin D (18) 


\begin{tabular}{|c|c|}
\hline \multicolumn{2}{|c|}{ ABBREVIATIONS } \\
\hline AIF & apoptosis-inducing factor \\
\hline CDDO-Me & methyl 2-cyano-3,12-dioxooleana-1,9(11)-dien- \\
\hline & 28-oate or bardoxolone methyl \\
\hline CSC & cancer stem-like cell \\
\hline Dap & dolaproine \\
\hline Dil & dolaisoleuine \\
\hline DLT & dose-limiting toxicities \\
\hline Dov & N,N-dimethyl-L-valine \\
\hline EMS & endometriosis \\
\hline ER & endoplasmic reticulum \\
\hline $\mathrm{EZH} 2$ & $\begin{array}{l}\text { the polycomb repressive complex } 2 \text { component } \\
\text { enhancer of zeste homologue } 2\end{array}$ \\
\hline G-Rh2 & 20(S)-ginsenoside $\mathrm{Rh}_{2}$ \\
\hline G-Rg3 & 20(S)-ginsenoside $\mathrm{Rg}_{3}$ \\
\hline G-Rh3 & ginsenoside $\mathrm{Rh}_{3}$ \\
\hline G-Rk2 & ginsenoside $\mathrm{Rk}_{2}$ \\
\hline Hsp90 & heat shock protein 90 \\
\hline IAP & inhibitors of apoptosis \\
\hline ICR & Institute of Cancer Research \\
\hline JNK & c-Jun $\mathrm{NH}_{2}$-terminal kinase \\
\hline $\mathrm{Gl}_{50}$ & concentration that inhibits $50 \%$ cell growth \\
\hline IFN- $y$ & interferon- $y$ \\
\hline i. p. & intraperitoneal \\
\hline i. v. & intravenous \\
\hline MAPK/ERK & $\begin{array}{l}\text { mitogen-activated protein kinase/ } \\
\text { extracellular signal-regulated kinase }\end{array}$ \\
\hline MDM2 & mouse double minute 2 homolog \\
\hline MDSC & myeloid-derived suppressor cells \\
\hline MTD & maximum tolerated dose \\
\hline NF- $\kappa \mathrm{B}$ & nuclear factor kappa B \\
\hline NK & natural killer \\
\hline NOZ & human gallbladder cancer cell line \\
\hline OA-MVL & $\begin{array}{l}\text { oleanolic acid-encapsulated multivesicular } \\
\text { liposome }\end{array}$ \\
\hline PPD & protopanaxadiol \\
\hline PPT & protopanaxatriol \\
\hline ROS & reactive oxygen species \\
\hline SAR & structure-activity relationship \\
\hline STAT3 & signal transducer and activator of transcription-3 \\
\hline TAM & tumor-associated macrophage \\
\hline TNF- $\alpha$ & tumor necrosis factor- $\alpha$ \\
\hline TRAIL & TNF-related apoptosis-inducing ligand \\
\hline Val & L-valine \\
\hline VEGF & vascular endothelial growth factor \\
\hline
\end{tabular}

\section{Introduction}

Higher plants have afforded 4 major well-established classes of approved cancer chemotherapeutic drugs, inclusive of compounds based on bisindole and camptothecin alkaloids, taxane diterpenoids, and podophyllotoxin lignans, with the cephalotaxine alkaloid, omacetaxine mepesuccinate, having been introduced clinically for this purpose more recently $[1,2]$. Natural products

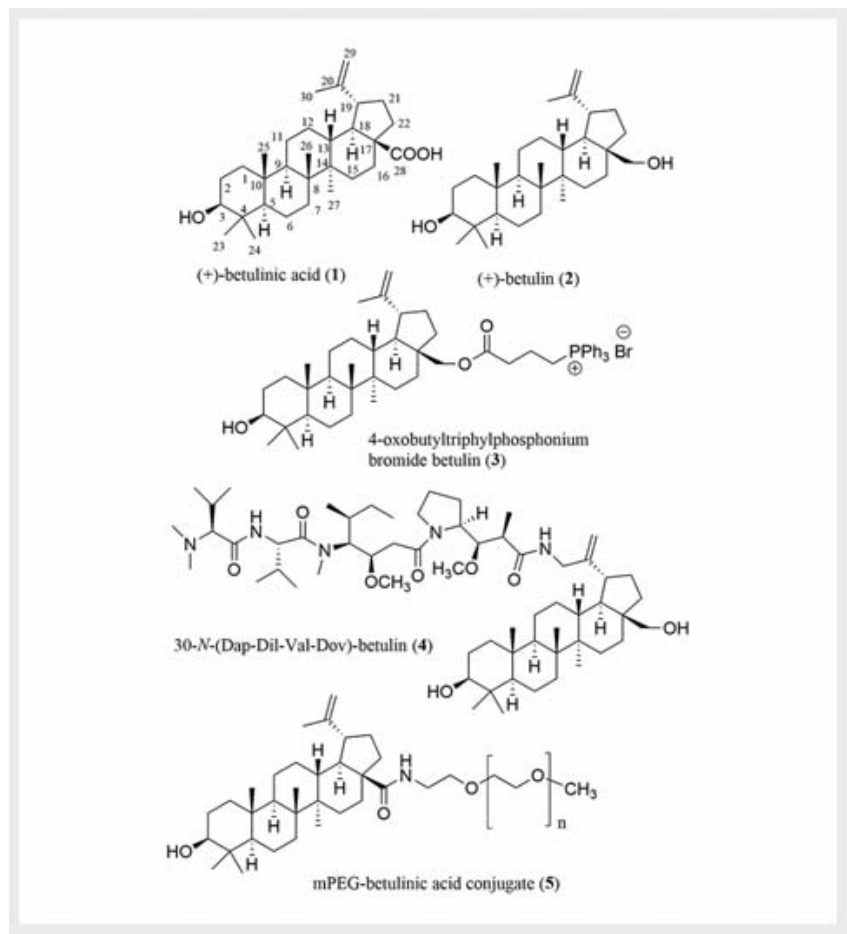

- Fig. 1 Structures of (+)-betulinic acid (1) and its natural and semi-synthetic derivatives (2-5) with potential anticancer activity.

from all classes of terrestrial and marine micro- and macro-organisms continue to play a vital role in drug discovery, inclusive of the search of new oncological agents. Indeed, of a total of 175 small molecules approved as anticancer drugs in western medicine from 1940 to 2014, approximately 50\% were either directly obtained from micro- and macro-organisms or derived synthetically from naturally occurring lead molecules [2,3].

The triterpenoids are a large group of over 20000 natural products derived from $C_{30}$ precursors, with over 100 different carbon skeletons, which are typically 6-6-6-5 tetracyclic and 6-6-6-6-5- or 6-6-6-6-6 pentacyclic substances [4,5]. The occurrence of triterpenoids in different types of organisms has been subjected to frequent review, with several hundred new compounds of this type described by investigators all over the world each year [6]. While neither naturally occurring nor semi-synthetic triterpenoids have current use as anticancer agents in Western medicine, bardoxolone methyl, a synthetic oleanane-type triterpenoid, has reached clinical trial recently for the potential treatment of cancer [7].

Several investigators have reviewed specifically various classes of naturally occurring triterpenoids as potential anticancer agents (e.g., $[5,8-16])$. The interest of the present authors on this same issue has been stimulated as a result of 2 long-standing collaborative multidisciplinary projects funded sequentially by the U.S. National Cancer Institute, in which numerous triterpenoids isolated from tropical plants collected in several continents were evaluated biologically $[17,18]$. A significant initial observation made in this work was the specific inhibitory activity in vitro of the pentacyclic triterpenoid, (+)-betulinic acid (1) ( $\bullet$ Fig. 1 ), against 3 different cancer patient-derived melanoma cell lines [19]. As part of 
the same study, follow-up in vivo work showed significant inhibition of tumor growth when 4-wk-old athymic nude mice inoculated with MEL-1 human melanoma cells were treated with compound 1 ( $5 \mathrm{mg} / \mathrm{kg}$, once 4 d, i. p.) for $6 \mathrm{wk}$, and neither tumor metastases nor structural abnormalities were observed in mice [19].

In the following portions of this review, our own recent experimental observations on biologically active plant-derived triterpenoids will be combined with descriptions of relevant work by other groups on triterpenoids having potential antineoplastic activity.

\section{Lupane-Type Triterpenoids}

As part of a recent summary account, further preclinical studies were described in a book chapter that led eventually to the evaluation of (+)-betulinic acid (1) in phase I/II clinical trials to treat dysplastic melanocytic nevi. These clinical trials were conducted at the College of Medicine, University of Illinois at Chicago, Chicago, IL, USA, with the drug administered topically as a $20 \%$ ointment [20].

Following this development, there is presently quite a large contemporary body of literature on efforts to generate additional anticancer agents based on (+)-betulinic acid (1) and its close analogue, (+)-betulin (2) ( Fig. 1), aimed at improving particularly both the antitumor efficacy and water solubility (e.g., [21-24]). It was realized in early work that the cytotoxic potency of (+)-betulinic acid (1) toward MEL-2 melanoma and KB human oral epidermoid carcinoma cells could be enhanced by altering the substituents at positions C-3, C-20, and C-28 [25]. As one synthetic approach, the inhibitory effects of (+)-betulin (2) were greatly enhanced on the proliferation of vincristine-resistant MCF-7 human breast cancer cells by introduction of a triphenylphosphonium cation conjugate at the C-28 position to produce 4-oxobutyltriphylphosphonium bromide betulin (3) ( $\triangleright$ Fig. 1), which showed an $\mathrm{IC}_{50}$ value of $45 \mathrm{nM}$ that was much lower than the positive controls, doxorubicin (IC $50.3 \mu \mathrm{M})$ and vinblastine $\left(\mathrm{IC}_{50} 9.2 \mu \mathrm{M}\right)$ [26]. Another potent cytotoxic agent produced is the chimera derivative, betulastatin 3 [30-N-(Dap-Dil-Val-Dov)-betulin] (4, > Fig. 1), which was prepared by bonding (+)-betulin $\left(2, \mathrm{Gl}_{50}>10 \mu \mathrm{g} / \mathrm{mL}\right)$ to the Dov-Val-Dil-Dap unit of the anticancer compound, dolastatin 10 , and showed a $\mathrm{Gl}_{50}$ value of $0.04 \mu \mathrm{g} / \mathrm{mL}$ against DU-145 human prostate cancer cells [27].

Recently, an important approach that has been undertaken is production of the mPEG-betulinic acid conjugate, 5 ( $\bullet$ Fig. 1), a more water-soluble derivative of compound 1 that also augments the cytotoxic potency of the parent compound, (+)-betulinic acid (1) [28].

\section{Oleanane-Type Triterpenoids}

$(+)$-Oleanolic acid (6) ( $\triangleright$ Fig. 2) is a pentacyclic triterpenoid that exhibits promising antitumor efficacy and has been found to interact with multiple molecular targets [29]. It showed cytotoxic and anti-metastatic activities against A549 and H460 human non-small cell lung cancer cells by decreasing the expression of the angiogenic VEGF and the development of melanoma-induced lung metastasis [30]. Also, it inhibited the proliferation of GBC-SD and NOZ human gallbladder cancer cells through the mitochon-

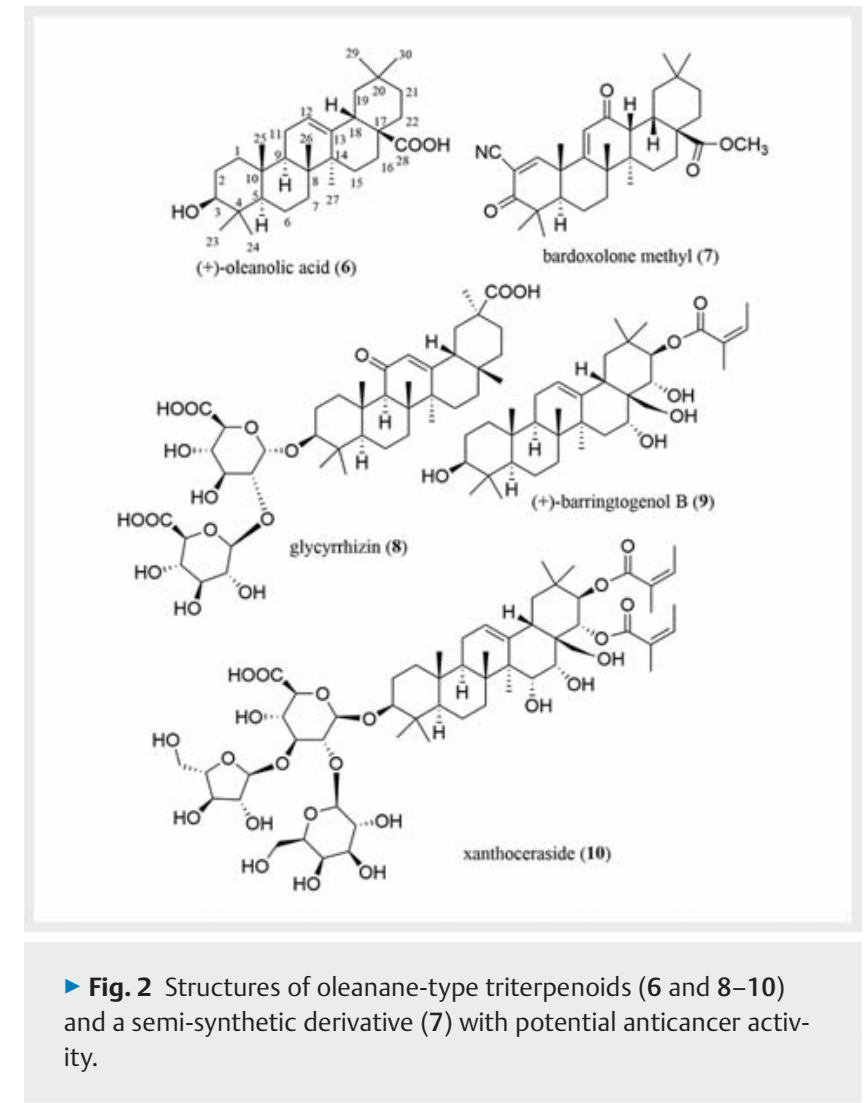

drial apoptosis pathway [31]. Tumor growth was suppressed significantly when 4- to 6-wk-old athymic male nude mice inoculated with NOZ cells were treated with (+)-oleanolic acid (i.p., 75 or $150 \mathrm{mg} / \mathrm{kg}$, once every $2 \mathrm{~d}$ ) for $15 \mathrm{~d}$, and no side effects were observed in the test mice used [31].

In addition, (+)-oleanolic acid (6) was found to inhibit mitomycin C-resistant HT-29 human colon cancer cell growth, which was proposed to be mediated through selective inhibition of human aldo-keto reductase [32]. It also inhibited HepG2 and SMC7721 hepatoma cell growth by suppression of the PI3K/Aкt1/mTOR signaling pathway and as a result of triggered ROS-dependent autophagy [33]. Interestingly, (+)-oleanolic acid (6) has been found to increase MDA-MB-231 human breast cancer cell migration and hence show promising properties for wound healing, an effect that was mediated by mitogen-activated protein kinases [34].

In a very recent study, (+)-oleanolic acid (6) was found to induce MG63 and Saos-2 human osteosarcoma cell apoptosis by targeting mitochondria in a Notch signaling-dependent manner [35]. By acting via a diverse range of cellular mechanisms, this endorses the potential of (+)-oleanolic acid for further development as an antitumor agent.

To improve on the solubility and therapeutic efficacy of (+)-oleanolic acid (6), a novel dosage form has been developed and evaluated, namely, (+)-OA-MVLs. In a side-by-side comparison, this liposomal form of $(+)$-oleanolic acid showed an enhanced tumor growth inhibitory effect with respect to compound 6 when male Kunming mice inoculated with murine hepatoma $\mathrm{H} 22$ cells were treated (i. p.) with (+)-oleanolic acid (6) or OA-MVLs $(25,50$, or 
$100 \mathrm{mg} / \mathrm{kg}$ for each compound, once $2 \mathrm{~d}$ ) for $2 \mathrm{wk}$. The survival time of the tumor-bearing mice was increased by both treatments, and no body weight loss was observed in the OA-MVL treatment protocol, even at a high dose $(100 \mathrm{mg} / \mathrm{kg})$ [36].

As a result of structural modification at the $\mathrm{C}-3$ and $\mathrm{C}-28$ positions of (+)-oleanolic acid (6), the novel analogue, CDDO-Me, or RTA 402 (7) ( $\bullet$ Fig. 2), was synthesized [37]. This derivative inhibited potently production of nitric oxide induced by IFN- $y$ in mouse macrophages [37]. It also showed cytotoxicity against HepG2 human hepatoma and B16 2F10 mouse melanoma cells [38]. In addition, CDDO-Me (7) was found to redirect the activation profile of TAMs, enhancers of tumor growth, development, and metastasis, from tumor-promoting to tumor-inhibiting, indicating a possible immunotherapeutic role in the treatment of cancer [39].

Increasingly, a number of investigations on CDDO-Me (7) have shown that this agent exhibited potent cytotoxicity toward various tumor cells to exert promising in vivo antitumor efficacy [40]. For example, it showed strong antiproliferative and proapoptotic activity against the MiaPaCa-2 and BxPC-3 human pancreatic ductal adenocarcinoma cell lines. Tumor growth was inhibited significantly when 7-wk-old SCID-NCr female mice inoculated with MiaPaCa-2 cells were treated with CDDO-Me (7) (gavage, $7.5 \mathrm{mg} / \mathrm{kg}$, daily, $5 \mathrm{~d} / \mathrm{wk}$ ) for $5 \mathrm{wk}$ [41].

The antitumor efficacy of CDDO-Me (7) was found to be mediated by improving the immune response in cancer. Tumor growth was found to be inhibited significantly by CDDO-Me (7) when 6- to 8-wk-old C57BL/6 female mice that were inoculated with EL-4 mouse thymoma cells and then vaccinated with dendritic cells transduced with full-length survivin were treated with CDDO-Me (7) (oral chow, $150 \mathrm{mg} / \mathrm{kg}$, daily, $4 \mathrm{~d} / \mathrm{wk}$ ) for $3 \mathrm{wk}$ [42].

In a phase I clinical trial study, patients with locally advanced or metastatic pancreatic adenocarcinoma were treated with gemcitabine (i.v., weekly) and CDDO-Me (7, orally, daily), with immunology evaluated before and after the 2-wk treatment. Neither toxicity attributed to compound 7 nor significant change of the proportion of MDSC mainly responsible for immune suppression in cancer was observed in the patients. Combined CDDO-Me and gemcitabine treatment resulted in a significant increase in the Tcell responses of the patients to tetanus toxoid and phytohemagglutinin, indicating the therapeutic promise of this triterpenoid derivative in enhancing cancer immunotherapy [42].

A further phase I study on CDDO-Me in patients with advanced solid tumors or lymphomas has been reported, with its MTD, DLTs, and appropriate dose for phase II studies established [7, 43]. However, this clinical trial on CDDO-Me was suspended due to some serious adverse events evident, indicating that further structural modification is required to decrease the side effects observed for this triterpenoid derivative (7), for future development of an effective anticancer agent [44].

The sweet-tasting oleanane-type triterpene glycoside glycyrrhizin (8) ( $\triangleright$ Fig. 2) is used as an ingredient in the food and beverage industry and is the major active constituent of Glycyrrhiza glabra L. (licorice) (Fabaceae) [45]. This and 2 other Glycyrrhiza species are official sources of licorice in the Chinese Pharmacopoeia, with G. glabra demonstrated as having anti-inflammatory, antioxidant, antiviral, hepatotoxic, and neuroprotective propensities [46].
Among recent reports on the antitumor potential of glycyrrhizin (8), its cytotoxicity toward HepG2 and MHCC97-H hepatocellular carcinoma cells was found to be mediated by autophagy induced from the inhibition of Akt/mTOR signaling [47]. It is worth mentioning that Glycyrrhiza uralensis Fisch. containing glycyrrhizin (8) is used as a component of PHY906, which is a long-established 4-herb formula used in Chinese traditional medicine to treat a number of gastrointestinal conditions and to improve the therapeutic indices of a number of standard anticancer agents [48].

In a murine colon xenograft model, PHY906 enhanced significantly the antitumor activity and reduced the toxicity of irinotecan (CPT-11) when tumor-bearing mice were treated by CPT-11 (i. p., $360 \mathrm{mg} / \mathrm{kg}$, daily) with (500 mg/kg, orally, twice a day) or without PHY906 for 4 consecutive days [49].

In a phase II study conducted in the United States using PHY906 with capecitabine as second-line therapy in patients with advanced pancreatic cancer, it was concluded that this combination may provide a safe and feasible salvage therapy for such patients after failure using gemcitabine [50].

As an additional example of a group of oleanane-type triterpenoids, compounds related to barrigenol represent a small group of olean-12-enes hydroxylated at the C-3, C-15, and/or C-16, C22 and/or C-21, and C-28 positions, which occur mainly in the plant families Apocynaceae, Lecythidaceae, Pittosporaceae, Sapindaceae, and Theaceae. In our continuing search for anticancer agents from tropical plants, a barrigenol-like triterpenoid, (+)-barringtogenol B (9) ( Fig. 2), was isolated as a major cytotoxic component from an extract of the bark of Cyrilla racemiflora L. (Cyrillaceae), collected in Dominica [51]. This compound exhibited an $\mathrm{IC}_{50}$ value of $1.7 \mu \mathrm{M}$ for HT-29 human colon cancer cells (the positive control, paclitaxel, showed an $\mathrm{IC}_{50}$ value of $0.8 \mathrm{nM}$ ) [51]. A preliminary SAR study showed that an angeloyl group attached at either C-21 or C-22 is necessary for barrigenol-like triterpenoids to mediate their cytotoxicity. The presence of a hydroxy group at the $\mathrm{C}-24$ position enhances the cytotoxicity of some barrigenollike triterpenoids, but introducing a hydroxy group at the C-15 position results in the potency being decreased [51].

Based on these SAR conclusions, xanthoceraside (10) ( $\vee$ Fig. 2), a barrigenol-like triterpenoid isolated from the husks of Xanthoceras sorbifolia Bunge (Sapindaceae), with an angeloyl group substituted at C-21 and C-22, a hydroxy group connected at $\mathrm{C}-15, \mathrm{C}-16$, and $\mathrm{C}-28$, and a tri-glycoside unit linked at the C-3 position, was found to be cytotoxic against A375.S2 human melanoma cells $\left(\mathrm{IC}_{50} 5.71 \mu \mathrm{M}\right)$ but non-cytotoxic against normal peripheral blood mononuclear cells, indicating a selective cytotoxicity for 10. Mechanistic studies showed that xanthoceraside (10) induced A375.S2 cell apoptosis by activating caspase-3 and caspase- 9 through the mitochondrial pathway that was induced by the downregulation of the IGF-1R/Raf/MEK/ERK cascade in A375. S2 cells [52]. These results indicate that the barrigenol-like triterpenoids may be worthy of further investigation for development as new anticancer agents. 


\section{Ursane-Type Triterpenoids}

There is an increasing interest in the potential antineoplastic propensities of the ursane-type triterpenoid, (+)-ursolic acid (11, - Fig. 3, e.g. $[8,10,12,15,53])$, and a number of pertinent studies published in the last decade seem worthy of mention. (+)-Ursolic acid (11) suppressed the proliferation of androgen-independent DU145 and androgen-dependent LNCaP human prostate cancer cells through inhibition of NF- $K$ B and STAT3 activation. Tumor growth was suppressed significantly when 4-wk-old athymic BALB/c male nude mice inoculated with DU145 cells were treated with (+)-ursolic acid (i. p., $200 \mathrm{mg} / \mathrm{kg}$, twice a week) for $6 \mathrm{wk}$. No significant effects on body weight were observed in mice [53].

In both in vitro and in vivo studies, (+)-ursolic acid (11) inhibited the proliferation of R-HepG2 doxorubicin-resistant human hepatoma cells by inducing apoptosis through the caspase-independent AIF signaling pathway [54]. Tumor growth was suppressed significantly when 4- to 6-wk-old female nude mice inoculated with R-HepG2 cells were treated with (+)-ursolic acid (orally, 50 or $75 \mathrm{mg} / \mathrm{kg}$, daily) for $2 \mathrm{wk}$. No significant effects on the body weight, liver, heart, and spleen of mice were observed [54].

Interestingly, (+)-ursolic acid (11) has been found to inhibit the growth of SKOV3 sphere human ovarian CSCs. In an in vivo study, tumor growth was inhibited significantly when 5- to 6-wk-old athymic BALB/C-nu female nude mice inoculated with SKOV3 sphere CSCs were treated with (+)-ursolic acid alone (i. p., $60 \mathrm{mg} /$ $\mathrm{kg}$, daily) or with (+)-ursolic acid (i. p., $60 \mathrm{mg} / \mathrm{kg}$, daily) plus cisplatin (i. p., $2.5 \mathrm{mg} / \mathrm{kg}$, daily) for $2 \mathrm{wk}$ [55].

In our collaborative work on tropical plants, Syzygium corticosum (Lour.) Merr. \& L. M. Perry (Myrtaceae), collected in Vietnam, showed some promise in preliminary biological screening and was thus subjected to activity-guided fractionation. Separation of the active extract from this species yielded a large amount of (+)-ursolic acid ( 11 , with a yield of $0.2 \% \mathrm{w} / \mathrm{w})$. This compound displayed a more potent NF- $\kappa$ B inhibitory activity $\left(\mathrm{IC}_{50} 31 \mathrm{nM}\right)$ than the positive control rocaglamide ( $\left(\mathrm{C}_{50} 70 \mathrm{nM}\right)$. It also exhibited activity against MDA-MB-231 breast cancer cells $\left(\mathrm{IC}_{50}\right.$ value of $\left.5.9 \mu \mathrm{M}\right)$ (the positive control, paclitaxel, showed an $\mathrm{IC}_{50}$ value of $17 \mathrm{nM}$ ) and was identified as the major cytotoxic principle of $S$. corticosum [56].

To characterize the functional groups necessary for mediation of its biological activity, 2 derivatives, (+)-uvaol (12) and (+)-3-O(4-chlorobenzoyl)ursolic acid (13) ( $\triangleright$ Fig.3) were synthesized from (+)-ursolic acid (11). However, both semi-synthetic products (12 and 13) were found to be inactive, indicating the importance of the presence of both the C-3 hydroxy and C-28 carboxylic acid groups [56]. Following this observation, a preliminary SAR study using some semi-synthetic analogues indicated that the C-3 hydroxy and C-28 carboxylic acid groups and 19,20-dimethyl substitution are all essential for (+)-ursolic acid to mediate its cytotoxicity toward MDA-MB-231 breast cancer cells and NF- $\kappa B$ inhibitory activity [56].

Consistently, an earlier SAR study showed that the presence of a C-28 keto carbonyl group is important for pentacyclic triterpenes to inhibit mouse melanoma B16 2F2 cell growth by induction of cell differentiation [57]. Thus, the antiproliferative activity of (+)-ursolic acid (11) against all of A549 non-small cell lung,

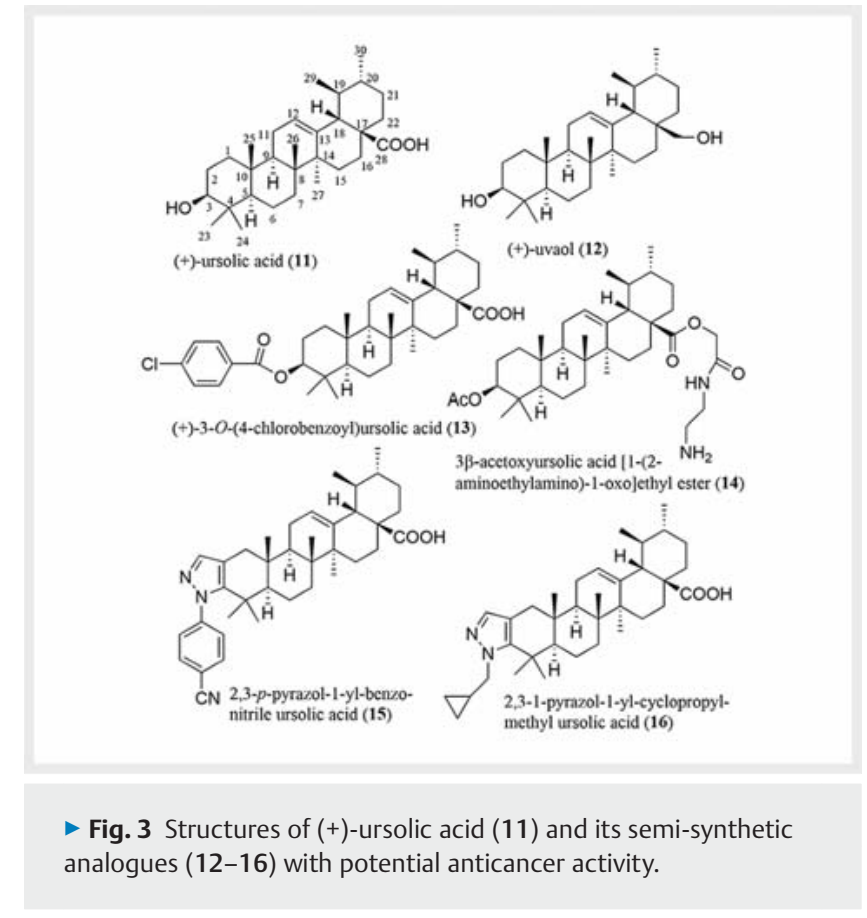

HeLa cervical, and MCF-7 breast human cancer cells was improved somewhat by modification at the $\mathrm{C}-28$ position via esterification followed by amidation with amines. One of these semi-synthetic products, $3 \beta$-acetoxyursolic acid [1-(2-aminoethylamino)-1-oxo] ethyl ester (14) ( $\mathbf{F i g . 3}$ ), was found to exhibit discernible cytotoxicity, showing an $\mathrm{IC}_{50}$ value in the range 8-10 $\mu \mathrm{M}$, while, the $\mathrm{IC}_{50}$ values of (+)-ursolic acid (11) were greater than $100 \mu \mathrm{M}$ for all these 3 cancer cell lines used [58].

In addition, a series of novel pyrazole-fused (+)-ursolic acid derivatives was synthesized in a further structural modification of (+)-ursolic acid (11) by introduction of a pyrazole moiety at its C2 and $C-3$ positions. Among these semi-synthetic derivatives, both a 2,3-p-pyrazol-1-yl-benzonitrile ursolic acid (15) ( Fig. 3) and a 2,3-1-pyrazol-1-yl-cyclopropylmethyl ursolic acid (16) (• Fig.3) showed more potent cytotoxicity than either the other pyrazolefused derivatives produced or the parent compound (11) toward a small panel of human cancer cell lines [59]. Surprisingly, compound $\mathbf{1 5}$ was found to induce HeLa human cervical cancer cell death through hyperstimulation of micropinocytosis, which can induce methuosis, a non-apoptotic type of cell death. This may provide a useful probe for the development of new cancer therapeutic agents to combat the multidrug resistance problem [59].

To improve on its water solubility for potential clinical applications, a carrier-free nanodrug by self-assembly of (+)-ursolic acid (11) has been developed, as a result of which the inhibitory effects on proliferation of A549 human lung cancer cells were found to be enhanced. Also, tumor growth was inhibited significantly when 6to 8-wk-old BALB/c-nu female nude mice inoculated with A549 cells were treated with $(+)$-ursolic acid $(11)$ or with $(+)$-ursolic acid-nanoparticles (i. p., $8 \mathrm{mg} / \mathrm{kg}$, daily) for $3 \mathrm{wk}$, and in addition, the population of $\mathrm{CD}^{+} \mathrm{T}$-cells in the mice was increased. These results indicate that this (+)-ursolic acid-nanoparticle carrier-free nanodrug has the potential for use in cancer immunotherapy [60]. 
Mechanistically, (+)-ursolic acid (11) mediates its antitumor potential through inhibition of NF- $\kappa$ B activation induced by carcinogenic agents with targets at cyclooxygenase 2, matrix metalloproteinase 9, and cyclin D11 [61]. It also inhibits tumor growth through other promising mechanisms involving angiogenesis and metastasis [53]. In a phase I study to assess the multiple-dose tolerability, efficacy, and pharmacokinetics of a liposomal form of (+)-ursolic acid, patients with confirmed advanced solid tumors were administered with this drug candidate intravenously for 14 consecutive days of a $21-d$ treatment cycle. The (+)-ursolic acid liposome used was found to be safe and well-tolerated and showed improved potential for improving patient remission rates. Accordingly, a phase II study was recommended for this (+)-ursolic acid liposome drug candidate [62].

\section{Cucurbitane-Type Triterpenoids}

Cucurbitacins are highly oxygenated cucurbitane-type tetracyclic triterpenoids that were identified initially from the plant family Cucurbitaceae and have been divided into 12 major structural categories [63]. Members of this group of natural products have been reported for their promising anticancer and anti-inflammatory activities [64], of which (+)-cucurbitacins B (17) and D (18) and (-)-cucurbitacins E (19) and I (20) have been investigated extensively for their cytotoxicity toward several human cancer cell lines ( $\triangleright$ Fig. 4) $[64,65]$. For example, $(+)$-cucurbitacin D (18) has been found to show potent cytotoxicity against a variety of human cancer cell lines, including human breast, central nervous system, colon, lung, oral epidermoid, and prostate cancer cells, with such activity mediated by induction of cell cycle arrest, mostly in the G2/M phase, and acting by modulating the JAKSTAT, Aкt-PKB, and MAPK pathways [63-65].

In a study conducted in our own laboratory, (+)-cucurbitacin D (18) was characterized as a major cytotoxic component against HT-29 human colon cancer cells from both the fruits and stem bark of Elaeocarpus chinensis (Gardner \& Champ.) Hook.f. ex Benth. (syn.: Friesia chinensis Gardner \& Champ.) (Elaeocarpaceae), collected in Vietnam, and showed an $\mathrm{IC}_{50}$ value of $0.12 \mu \mathrm{M}$ (the positive control, paclitaxel, showed an $\mathrm{IC}_{50}$ value of $6 \mathrm{nM}$ ) [66].

Analysis of the structures of these potently cytotoxic triterpenoids, including (+)-cucurbitacins B (17) and D (18) and (-)-cucurbitacins E (19) and I (20), shows that they all contain a C-2 hydroxy group, a ketocarbonyl group at the $\mathrm{C}-3$ and $\mathrm{C}-11$ positions, a double bond at the $\mathrm{C}-1$ and/or $\mathrm{C}-5$ positions, $16 \alpha, 20 \beta$-dihydroxy groups, a C-22 enone group, and a C-25 hydroxy or acetoxy group, indicating that these structural moieties could be important for a given cucurbitacin to mediate cancer cell-line cytotoxicity. This has been supported by a study examining the chemical structures of 24 cucurbitacins and determining their resultant cytotoxicity against KB human oral epidermoid carcinoma cells, which showed that the presence of an $\alpha, \beta$-unsaturated ketone and a C-25 acetoxy group, along with a free 16 $\alpha$-hydroxy group, are the most relevant structural features required for such activity [65].

An additional biological investigation showed that all of (+)-cucurbitacin D (18) and (-)-cucurbitacins E (19) and I (20) exhibited

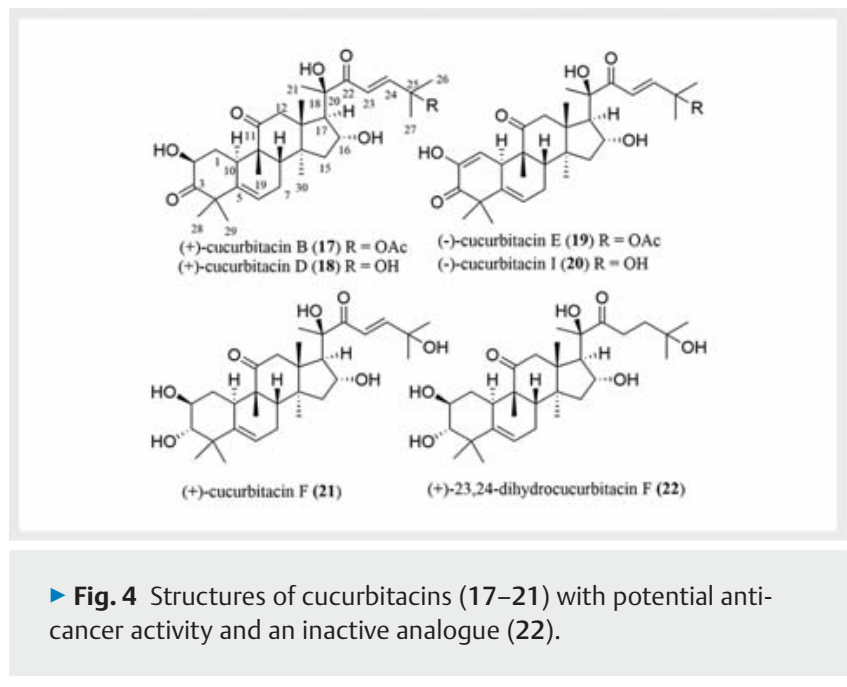

potent cytotoxicity against SW 1353 human chondrosarcoma cells, with the activity decreasing in the sequence 19,20 , and 18 [67]. This indicates that introduction of a C-1 enone group or replacement of C-25 hydroxy group with an acetoxy group could increase the cytotoxicity of (+)-cucurbitacin D (18) toward SW 1353 cells.

Consistent with these conclusions, (+)-cucurbitacin D (18) was found to exhibit around 10-fold more cytotoxic potency than (+)-cucurbitacin F (21) ( $\triangleright$ Fig. 4) against all of the A549 non-small cell lung cancer, HCT-15 colon cancer, SK-MEL-2 melanoma, SKOV3 ovarian cancer, and XF 498 human central nervous system human cancer cell lines. Furthermore, saturation of C-23 double bond in (+)-23,24-dihydrocucurbitacin $F(22)$ ( $\bullet$ Fig. 4) resulted in loss of activity $\left(\mathrm{IC}_{50}>50 \mu \mathrm{g} / \mathrm{mL}\right)$ against both $\mathrm{KB}$ human solid tumor and P-388 murine leukemia cells when compared with (+)-cucurbitacin F (21), which showed activity toward KB and P388 cells, with $\mathrm{IC}_{50}$ values of 0.074 and $0.04 \mu \mathrm{g} / \mathrm{mL}$, respectively $[68,69]$.

The antineoplastic potential of all (+)-cucurbitacins B (17) and D (18) and (-)-cucurbitacins E (19) and I (20) have been reviewed previously $[64,65]$. Briefly discussed below are an update of more recent studies on the anticancer potentials of the representative compound, (+)-cucurbitacin D (18).

$(+)$-Cucurbitacin D (18) has been found to suppress the proliferation of Hep3B human hepatoma cells [70], as well neurofibromatosis type 2 (Nf2)-deficient mouse Sch10545 schwannoma and telomerase-immortalized benign Ben-Men-1 human meningioma cells [71]. Also, this agent induced apoptosis in the doxorubicinresistant human MCF7/ADR breast cancer cells through inhibiting STAT3 and NF- $\kappa$ B signaling [72], and its inhibitory effects toward human $T$ cell leukemia cells were found to be associated with autophagy [73].

Interestingly, (+)-cucurbitacin D (18) was found to mediate cytotoxicity toward MCF-7 human breast cancer cells through disrupting interactions between Hsp90 and 2 co-chaperones, Cdc37 and p23 [74]. Tumor growth was inhibited significantly when 6wk-old female athymic nude mice inoculated with CaSki human cervical cancer cells were treated with (+)-cucurbitacin D (18) (injected intratumorally, $1 \mathrm{mg} / \mathrm{kg}, 3$ times a week) for $4 \mathrm{wk}$ [75]. 
All of (+)-cucurbitacins B (17) and D (18) and (-)-cucurbitacins $E(19)$ and I (20) are potently cytotoxic, and, in general, these triterpenoids are strong STAT3 inhibitors and thus show selective inhibitory activity toward the JAK/STAT pathway $[64,65]$. STAT3 is a promising target for the discovery of new anticancer drugs, and thus cucurbitacins 17-20 may accordingly prove useful in the treatment of human cancer targeting STAT3.

\section{Dammarane-Type Triterpenoids I: Ginsenoside Sapogenins}

In Chinese traditional medicine, the roots of Panax ginseng C. A. Meyer (ginseng) (Araliaceae), known locally as "renshen", are used as a complementary and alternative herbal supplement to support cancer chemotherapy [76]. The ginsenosides, containing mainly dammarane-type tetracyclic triterpene saponins, have been characterized as the major components of ginseng, and have attracted a great deal of attention owing to their promising bioactivities, including potential antitumor efficacy $[77,78]$. As one of the major sapogenins of these ginsenosides, 20(S)-protopanaxadiol [20(S)-PPD, 23] ( Fig. 5) has been well documented for its potent antitumor activity and is known mechanistically to induce tumor cell apoptosis and to suppress the NF-kB, JNK, and MAPK/ERK signaling pathways. It also exhibits anti-metastasis and anti-angiogenesis activities, as well as synergistic effects with existing anticancer drugs [78].

An in vitro study showed that 20(S)-PPD (23) exhibited only marginal activity toward a small panel of human cancer cell lines, with the $\mathrm{IC}_{50}$ values being in the range $20-80 \mu \mathrm{M}$ [79]. In contrast, its growth inhibitory effect against MDA-MB-231 triple-negative human breast cancer cells was more highly evident ( $\left.\mathrm{IC}_{50} 5.9 \mu \mathrm{M}\right)$, which was comparable to the potency determined for paclitaxel $\left(\mathrm{IC}_{50} 6.2 \mu \mathrm{M}\right)$ [80]. This sapogenin (23) induced SF188 and U87MG human glioma cell apoptosis and autophagy through both caspase-dependent and -independent pathways [81], and it also inhibited Hep-2 human laryngeal carcinoma cell proliferation through apoptosis induction caused by downregulation of the expression of the mTOR signaling pathway [82].

In an in vivo antitumor investigation, the sensitivity of radiotherapy to laryngeal carcinoma was found to be increased by 20 (S)-PPD (23). When BALB/c female nude mice (18-22 g) bearing Hep-2 laryngeal tumors were treated with 23 (i.p., $20 \mathrm{mg} / \mathrm{kg}$, once every $2 \mathrm{~d}$ ), ionizing radiation (IR) (5 Gy), or 23 (i. p., $20 \mathrm{mg} /$ $\mathrm{kg}$, once every $2 \mathrm{~d}$ ) plus IR (5 Gy) for $2 \mathrm{wk}$, tumor growth was inhibited significantly in both the individual and combined treatments, and the combination ( 23 plus IR) treatment caused more substantial decreases of tumor volume and weight [83].

In addition, an anti-colon tumor efficacy mediated through the TRAIL pathway was observed for 20(S)-PPD (23) when 4-wk-old athymic female nude mice inoculated with HCT-116-luc human colon cancer cells were treated with 23 (i.p., 25 or $50 \mathrm{mg} / \mathrm{kg}$, once 2 every days) for 4 wk [84].

It is worthy of note that 20(S)-PPD (23) significantly enhanced the antitumor action of 5-flurouracil (5-FU) when 4- to 6-wk-old BALB/c female nude mice inoculated with HCT-116-luc human colon cancer cells were treated (i. p.) with 5-FU $(30 \mathrm{mg} / \mathrm{kg})$ or com-

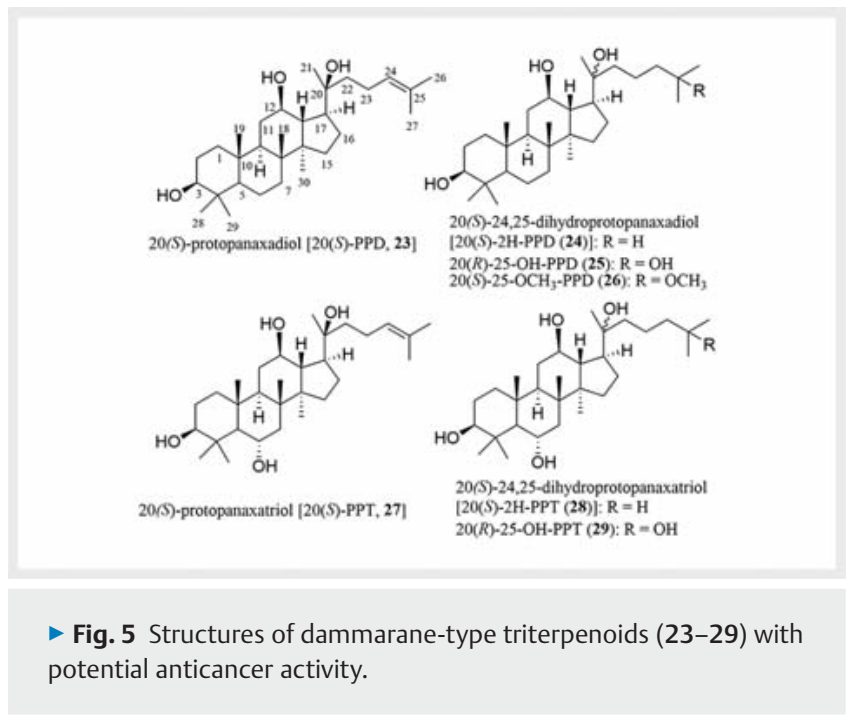

pound $23(15$ or $30 \mathrm{mg} / \mathrm{kg}$ ) plus 5-FU (30 mg/kg) once a week for $6 \mathrm{wk}[85]$.

Also, 20(S)-PPD (23) delayed the castration-resistant regrowth of LNCaP prostate tumors after androgen-deprivation therapy and inhibited castration-resistant 22Rv1 prostate tumor growth with endogenous expression of AR-FL and AR-Vs when male nude mice inoculated with LNCaP or 22Rv1 were treated with 20(S)-PPD (23) (gavage, $40 \mathrm{mg} / \mathrm{kg}$, daily, $6 \mathrm{~d} / \mathrm{wk}$ ) for $4 \mathrm{wk}$ [86]. A very recent investigation on the role of 20(S)-PPD (23) in EMS showed its antiEMS activity, which was mediated possibly by control of estrogenmediated autophagy regulation and improved NK cell cytotoxicity [87].

To increase its drug-like properties, nanosuspensions of 20(S)PPD (23) have been prepared, and its oral bioavailability was found to be improved when compared with the unmodified form of this compound [88]. An in vivo study showed that tumor growth was inhibited when ICR mice inoculated with $\mathrm{H} 22$ murine sarcoma cells were treated with nanosuspensions of compound 23 (injected via the lateral tail vein, 20,50 , or $100 \mathrm{mg} / \mathrm{kg}$, daily) for $9 \mathrm{~d}[88]$.

To identify the structural requirements for the activity, a hydrogenated derivative, 20(S)-24,25-dihydroprotopanaxadiol [20 (S)-2H-PPD (24), • Fig. 5], was synthesized from 20(S)-PPD (23), and this synthetic analogue showed less potent cytotoxicity toward MDA-MB-231 human breast cancer cells than the parent compound, 23 [80]. However, an analogous compound, 20(R)25-OH-PPD (25) ( $\vee$ Fig. 5), isolated from the fruits of $P$. ginseng, was found to show more potent cytotoxicity than 20(S)-PPD (23) toward a panel of human cancer cell lines. This cytotoxic sapogenin (25) was absorbed and distributed rapidly in the plasma and in the kidney, liver, spleen, and tumor tissues, after nude male mice bearing xenografts of human pancreatic tumors were treated (i.v. and oral) with this compound at doses of 10 and $20 \mathrm{mg} / \mathrm{kg}$, respectively, indicating its relatively favorable pharmacokinetic properties $[79,89]$.

Interestingly, a methylated sapogenin, 20(S)-25- $\mathrm{OCH}_{3}-\mathrm{PPD}$ (26) ( $\triangleright$ Fig. 5), isolated from the leaves of Panax notoginseng (Birkill) F. H. Chen ex C. H. Chow (Araliaceae) showed cytotoxicity to- 
ward SW620 human colon cancer cells, with the $\mathrm{IC}_{50}$ value being less than $5 \mu \mathrm{M}$. This sapogenin (26) induced LS174 and SW480 colon and A549 lung human cancer cell apoptosis by suppression of Wnt/ $\beta$-catenin signaling [90], and it also inhibited t- $\mathrm{HSC} / \mathrm{Cl}-6 \mathrm{mu}-$ rine hepatic stellate cell activation by inducing apoptosis and elevating the level of cellular glutathione, indicating that it exerts an antifibrosis effect on activated t-HSC/Cl-6 cells [91].

Both 20(R)-25-OH-PPD (25) and its close analogue, 20(R)-25$\mathrm{OCH}_{3}-\mathrm{PPD}$, were found to inhibit significantly the growth of human BGC-823, SGC-7901, and MKN-28 gastric cancer cells [92]. These 2 compounds also inhibited HPAC and PANC-1 human pancreatic cancer cell growth [93]. Pancreatic tumor growth was inhibited when 4- to 6-wk-old male athymic nude nu/nu mice inoculated by Panc- 1 cells were treated (i. p.) with both compounds separately (1, 5, or $10 \mathrm{mg} / \mathrm{kg}$, daily, $5 \mathrm{~d} / \mathrm{wk})$ for $6 \mathrm{wk}$ [93].

Mechanistically, 20(R)-25-OH-PPD (25) and 20(R)-25- $\mathrm{OCH}_{3}-$ PPD exhibited anti-pancreatic tumor efficacy partially through inhibition of the MDM2 oncogene and related pathways [93]. MDM2 protein is an important negative regulator of the p53 tumor suppressor and is regarded as a target for cancer chemotherapy. Thus, these 2 sapogenins show promise in terms of their potential anticancer activity targeting MDM2.

Importantly, 20(S)-25-OCH $-\mathrm{PPD}$ (26) was found to be tolerated at doses up to $600 \mathrm{mg} / \mathrm{kg}$, and no mortality and treatmentrelated toxicity were observed in Sprague-Dawley rats when the rats were treated orally with this compound (daily, 150, 300 and $600 \mathrm{mg} / \mathrm{kg}$ ) for 92 consecutive days [94]. Also, the water solubility of 20(S)-25- $\mathrm{OCH}_{3}$-PPD (26) was improved by synthetic derivatization reactions [95]. These support strongly the further development of 20(S)-25-OCH - -PPD (26) as a new anticancer agent.

Both 20(S)-PPD (23) and 20(S)-protopanaxatriol [20(S)-PPT, 27] ( $\triangleright$ Fig.5) are representative sapogenins of the ginsenosides, and these compounds were found to exhibit moderate cytotoxicity toward MDA-MB-231 human breast cancer cells. However, their hydrogenated derivatives, 20(S)-24,25-dihydroprotopanaxadiol [20(S)-2H-PPD (24)] and 20(S)-24,25-dihydroprotopanaxatriol [20(S)-2H-PPT (28)], were less potent than the parent compounds, 23 and 27 , respectively [80], indicating the functional importance of a C-24/25 double bond in these compounds. In addition, 20(S)-PPD (23) was more active than 20(S)-PPT (27) against MDA-MB-231 cells [80], showing that introducing an $\alpha$-hydroxy group at the C-6 position results in the cytotoxic potency of 20 (S)-PPD (23) being decreased. This was supported by the cytotoxicity observed for 20(R)-25-OH-PPD (25) and 20(R)-25-OH-PPT (29) toward a panel of human cancer cell lines, including breast, glioma, lung, pancreatic, and prostate cancer cells, for which 25 showed weak activity, with $\mathrm{IC}_{50}$ values in the range $10-70 \mu \mathrm{M}$, but 29 did not $\left(\mathrm{IC}_{50}>100 \mu \mathrm{M}\right)$ [79].

\section{Dammarane-Type Triterpenoids II: Ginsenosides}

In analogous work, the antitumor potential has been investigated extensively for the PPD-type ginseng saponins, including the 20(S)-ginsenosides $\mathrm{Rh}_{2}(\mathrm{G}-\mathrm{Rh} 2,30)$ and $\mathrm{Rg}_{3}(\mathrm{G}-\mathrm{Rg} 3,31)$, and ginsenosides $R h_{3}(G-R h 3,32)$, and $R k_{2}(G-R k 2,33)$ ( Fig. 6) [76, 78,

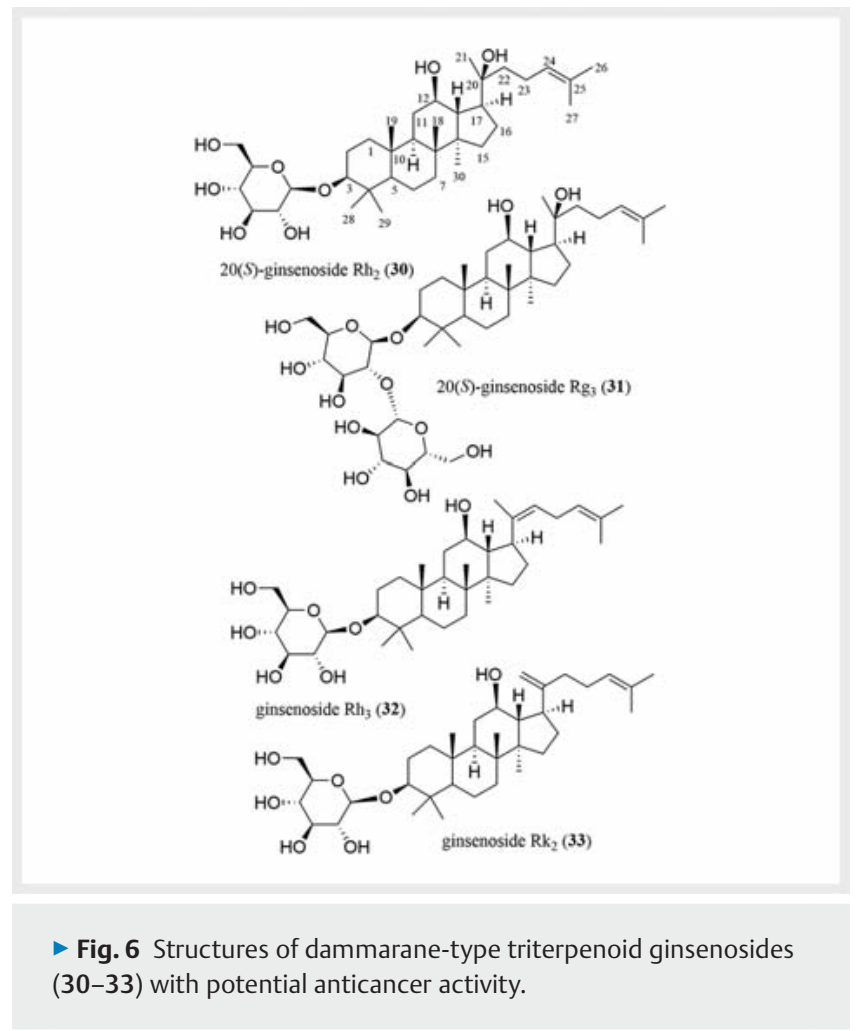

79, 96]. Of these, G-Rh2 (30) was up to 10 -fold more active than G-Rg3 (31) toward a panel of human cancer cells [79], indicating that introducing an additional sugar unit in the $\mathrm{C}-3$ saccharide moiety decreases the cytotoxic potency of G-Rh2 (30).

When 14 ginsenosides isolated from the steamed (heat-processed) leaves of $P$. ginseng were evaluated for their cytotoxicity toward HL-60 human leukemia cells, G-Rh2 (30), G-Rh3 (32), and G-Rk2 (33) were found to be active, while 32 and 33 were the most potently active, showing $\mathrm{IC}_{50}$ values of 0.8 and $0.9 \mu \mathrm{M}$, respectively [97], indicating that a double bond at the C-20(21) or C-20(22) position enhances the cytotoxicity of G-Rh2 (30).

The antineoplastic potential of various ginsenosides has been reviewed previously [78], and thus presented immediately below is an update of this topic, with G-Rh2 (30) being used as a representative example.

In recent studies, G-Rh2 (30) was found to significantly suppress cell proliferation, invasion, and migration in HEC1A human endometrial cancer cells [98], and it also decreased the viability of U87MG and A172 human glioma cells [99]. It induced ROS-mediated ER stress-dependent apoptosis in H1299 human lung cancer cells [100] and induced apoptosis in KG-1a human leukemia cells [101].

In an in vivo study, hepatoma growth was inhibited significantly when 18-22-g female mice inoculated with $\mathrm{H} 22$ murine hepatoma cells were gavaged with G-Rh2 (30) (3 or $4 \mathrm{mg} / \mathrm{kg}$, daily) for $10 \mathrm{~d}$ [102]. A further study showed that hepatoma growth was inhibited significantly, and the serum IL-2 levels, TNF- $\alpha$ production, T lymphocytes, $\mathrm{CD}^{+} / \mathrm{CD}^{+}$ratio, and NK cell levels of mice were increased when 7- to 8-wk-old male Kunming mice inoculated with $\mathrm{H} 22$ cells were gavaged with G-Rh2 (30) (5 or $10 \mathrm{mg} / \mathrm{kg}$, dai- 
ly) for $15 \mathrm{~d}$. This indicates that G-Rh2 mediates its antitumor activity partially through modulation of the immune system [103]. No obvious toxicity was observed in the mice used in these in vivo studies $[102,103]$.

Mechanistically, G-Rh2 (30) exhibits its potential antitumor activity through modulating the $A \kappa t$ and $W n t / \beta$-catenin signaling pathways [99, 101]. It targets EZH2, a potent histone methyltransferase that catalyzes the trimethylation of histone 3 and lysine 27 [104], downregulates the expression of the IAP apoptosis inhibitors, and synergizes with Annexin A2 inactivation to promote apoptosis [105]. Both EZH2 and Annexin A2 are over-expressed in liver cancer, and thus G-Rh2 (30) has been regarded as a promising candidate agent for targeted liver cancer therapy [105].

Interestingly, G-Rh2 (30) was found to mediate its antitumor efficacy by modulating the immune response $[103,106]$. G-Rh2 (30) triggered CD4 ${ }^{+}$and CD8a ${ }^{+}$T-lymphocyte infiltration in tumor tissues and increased T-lymphocyte cytotoxicity. An enhanced antitumor immunological response contributes to preventing the recurrence of cancer, and thus, G-Rh2 (30) could serve as an adjuvant for use with existing cancer chemotherapeutic agents [106].

\section{Dichapetalin-Type Triterpenoids}

A final group of triterpenoids selected for inclusion in this review are compounds of the dichapetalin-type. These compounds constitute a small group of 13,30-cyclodammarano[4,3]pyran derivatives, with the first member, (+)-dichapetalin A (34) ( $\bullet$ Fig. 7), being reported from Dichapetalum madagascariense Poir. (Dichapetalaceae) in 1995. In this reference, the authors reported a greater susceptibility of (+)-dichapetalin A (34) against the L1210 murine leukemia cell line $\left(\mathrm{EC}_{90}<0.0001 \mu \mathrm{g} / \mathrm{mL}\right)$ than against the KB human oral epidermoid carcinoma cell line [107]. This trend was noted also by Tuchinda et al., for their isolate (+)-acutissmatriterpene E (35) ( $\bullet$ Fig. 7) from Phyllanthus acutissima Miq. (Phyllanthaceae), which was more potently cytotoxic for the P-388 murine lymphocytic leukemia cell line $\left(\mathrm{IC}_{50} 0.005 \mu \mathrm{g} /\right.$ $\mathrm{mL}$ ) than for the other human cancer cell lines evaluated, using ellipticine ( $\mathrm{IC}_{50} 0.2 \mathrm{\mu g} / \mathrm{mL}$ toward P-388 cells) as the positive control [108].

The interest of our group in this class of compounds was stimulated by the isolation of several cytotoxic dichapetalins from the stem bark of Dichapetalum gelonioides (Roxb.) Engl. (Dichapetalaceae) collected in the Philippines, among which (+)-dichapetalin A (34) exhibited its most potent cytotoxic effects toward the SW626 human ovarian cancer cell line ( $\left.I_{50} 0.2 \mu \mathrm{g} / \mathrm{mL}\right)$. Also obtained in this study were the new (+)-dichapetalins I (36) and J (37) ( $\bullet$ Fig. 7), which again demonstrated their most potent cytotoxic activity for SW626 cells ( $\mathrm{IC}_{50} 0.5$ and $0.4 \mu \mathrm{g} / \mathrm{mL}$, respectively) [109].

However, when tested in a follow-up in vivo hollow fiber assay, $(+)$-dichapetalin A (34) was inactive when tested in mice at doses of $1,2,4$, and $6 \mathrm{mg} / \mathrm{kg}$ (i. p. administration) for 4 different types of human cancer cell lines, including SW626 cells [109]. In a more recent investigation by our group, a non-cytotoxic dichapetalin $\mathrm{A}$ analogue, (+)-songbodichapetalin (38) ( $\bullet$ Fig. 7), was isolated from the aerial parts of Phyllanthus songboiensis N. N. Thin (Phyllanthaceae) collected in Vietnam [110].

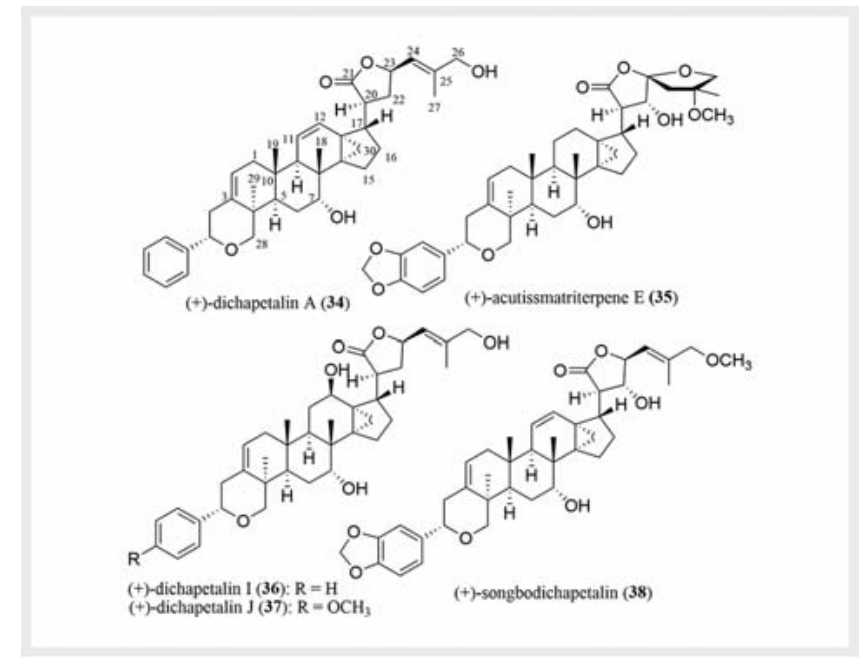

- Fig. 7 Structures of dichapetalin-type triterpenoids (34-37) with potential anticancer activity and their inactive analogue (38).

Analysis of the dichapetalin derivatives and their cytotoxic activity against cancer cell lines indicates that a methylenedioxy group connected at the $\mathrm{C}-3^{\prime}$ and $\mathrm{C}-4^{\prime}$ position is not required for this type of activity, but the presence of a hydroxy group at the C22 position can enhance cytotoxicity. In addition, a primary C-26 hydroxy group seems to play a key role in determining the cytotoxic potency of the dichapetalin-type triterpenes $[108,110]$. These preliminary SAR conclusions indicate that the antitumor potential of the dichapetalins could be improved by synthetic modification. Owing to their inherently potent cytotoxic potency for certain cancer cell lines, this group of cyclodammarane-type triterpene lactones seems worthy of additional in vivo antineoplastic testing and mechanism-of-action studies.

\section{Conclusions}

Plant-derived triterpenoids were frequently encountered along with more promising compounds in early anticancer screening campaigns. However, this type of natural products was deemed to be of insufficient promise for further development or more indepth biological investigation because of their general lack of potency in inhibiting the growth of the panels of murine and human cancer cell lines. Fortunately, over the last nearly $20 \mathrm{y}$, there has been an undeniable uptake of interest in the antitumor activities of triterpenoids, which have been supported by promising effects observed in vivo and by supportive mechanism-of-action investigations. For example, (+)-ursolic acid (11), a pentacyclic triterpenoid distributing widely in plants, modulates several important inflammation-associated signaling pathways, including NF- $\kappa$ B, STAT3, and TRAIL signalings, and has reached cancer clinical trials [111]. Several triterpenoids decrease the expression of specificity protein transcription factors in cancer cells. They also induce ROS, an important proteasome-independent pathway for downregulation of specificity protein transcription factors and activate or deactivate nuclear receptors and G-protein coupled receptors, which contribute to their antitumorigenic activity [112]. In this re- 
gard, the recent progress made on plant triterpenoids as potential cancer chemotherapeutic agents is analogous to that made on sesquiterpene lactones of plant origin [113].

Isolation chemistry work on a given cytotoxic plant lead tends to afford a suite of structurally related active compounds and permits an initial evaluation of structure-cytotoxicity relationships, which in turn may guide the subsequent synthesis of more potent analogues of a bioactive compound. New techniques of formulation, such as the production of liposomes and nanoparticules of triterpenoids, have enabled both the resultant water solubility and bioavailability of the lead compounds to be enhanced. A range of mechanistic effects on cancer cells have been shown for the triterpenoids, including inhibition of NF- $\kappa \mathrm{B}$ and the induction of autophagy and/or the modulation of the human immune system. These mechanisms may contribute to limiting multidrug resistance, and thus, it may be confidently predicted that naturally occurring triterpenoids and their semi-synthetic derivatives will remain as promising leads for the development of new anticancer drugs in future years.

\section{Acknowledgements}

The experimental studies by our group mentioned in this article were supported by grants U19 CA52956 and P01 CA125066 funded by the National Cancer Institute, NIH, Bethesda, MD, USA. We are very grateful to many faculty colleagues, research staff, postdoctoral fellows, and graduate students who have contributed to this work.

\section{Conflict of Interest}

The authors declare no conflict of interest, financial or otherwise.

\section{References}

[1] Cragg GM, Kingston DGl, Newman DJ, eds. Anticancer Agents from Natural Products, 2nd ed. Boca Raton: CRC Press/Taylor \& Francis; 2012

[2] Butler MS, Robertson AAB, Cooper MA. Natural product and natural product derived drugs in clinical trials. Nat Prod Res 2014; 31: 16121661

[3] Newman D], Cragg GM. Natural products as sources of new drugs from 1981 to 2014. J Nat Prod 2016; 79: 629-661

[4] Xu R, Fazio GC, Matsuda SPT. On the origins of triterpenoid skeletal diversity. Phytochemistry 2004; 65: 261-291

[5] Petronelli A, Pannitteri G, Testa U. Triterpenoids as new promising anticancer drugs. Anticancer Drugs 2009; 20: 880-892

[6] Hill RA, Connolly JD. Triterpenoids. Nat Prod Rep 2017; 34: 90-122

[7] Hong DS, Kurzrock R, Supko JG, He X, Naing A, Wheler J, Lawrence D, Eder JP, Meyer CJ, Ferguson DA, Mier J, Konopleva M, Konoplev S, Andreeff M, Kufe D, Lazarus H, Shapiro Gl, Dezube BJ. A phase I first-inhuman trial of bardoxolone methyl in patients with advanced solid tumors and lymphomas. Clin Cancer Res 2012; 18: 3396-3406

[8] Baglin I, Mittaine-Offer AC, Nour M, Tan K, Cavé C, Lacaille-Dubois MA. A review of natural and modified betulinic, ursolic, and echinocystic acid derivatives as potential antitumor and anti-HIV agents. Mini Rev Med Chem 2003; 3: 525-539

[9] Setzer WN, Setzer MC. Plant-derived triterpenoids as potential antineoplastic agents. Mini Rev Med Chem 2003; 3: 540-546

[10] Laszczyk MN. Pentacyclic triterpenes of the lupane, oleanane and ursane group as tools in cancer therapy. Planta Med 2009; 75: 1549-1560
[11] Kuo RY, Qian K, Morris-Natschke SL, Lee KH. Plant-derived triterpenoids and analogues as antitumor and anti-HIV agents. Nat Prod Rep 2009; 26 : 1321-1344

[12] Salvador JAR, Moreira VM, Gonçlaves BMF, Leal AS, Jing Y. Ursane-type pentacyclic triterpenoids as useful platforms to discover anticancer drugs. Nat Prod Rep 2012; 29: 1463-1479

[13] Shanmugam MK, Nguyen AH, Kumar AP, Tan BKH, Sethi G. Targeted inhibition of tumor proliferation, survival, and metastasis by pentacyclic triterpenoids: potential role in prevention and therapy of cancer. Cancer Lett 2012; 320: 158-170

[14] Kamble SM, Goyal SN, Patil CR. Multifunctional pentacyclic triterpenoids as adjuvants in cancer chemotherapy: a review. RSC Adv 2014; 4: 33370-33382

[15] Salvador JAR, Leal AS, Valdeira AS, Gonçlaves BMF, Alho DPS, Figueiredo SAC, Silvestre SM, Mendes VIS. Oleanane-, ursane-, and quinone methide freidelane-type triterpenoid derivatives: recent advances in cancer treatment. Eur J Med Chem 2017; 142: 95-130

[16] Peron G, Marzaro G, Dall'Acqua S. Known triterpenes and their derivatives as scaffolds for the development of new therapeutic agents for cancer. Curr Med Chem 2018; 25: 1259-1269

[17] Kinghorn AD, Farnsworth NR, Soejarto DD, Cordell GA, Pezzuto JM, Udeani GO, Wani MC, Wall ME, Navarro HA, Kramer RA, Menendez AT, Fairchild CR, Lane KE, Forenza S, Vyas DM, Lam KS, Shu YZ. Novel strategies for the discovery of plant-derived anticancer agents. Pure Appl Chem 1999; 71: 1611-1618

[18] Kinghorn AD, Carcache de Blanco E], Lucas DM, Rakotondraibe HL, Orjala J, Soejarto DD, Oberlies NH, Pearce CJ, Wani MC, Stockwell BR, Burdette JE, Swanson SM, Fuchs JR, Phelps MA, Xu L, Zhang X, Shen YY. Discovery of anticancer agents of diverse natural origin. Anticancer Res 2016; 36: 5623-5637

[19] Pisha E, Chai H, Lee IS, Chagwedera TE, Farnsworth NR, Cordell GA, Beecher CWW, Fong HHS, Kinghorn AD, Brown DM, Wani MC, Wall ME, Hieken TJ, Das Gupta TK, Pezzuto JM. Discovery of betulinic acid as a selective inhibitor of human melanoma that functions by induction of apoptosis. Nat Med 1995; 1: 1046-1051

[20] Henkin JM, Ren Y, Soejarto DD, Kinghorn AD. The Search for Anticancer Agents from Tropical Plants. In: Kinghorn AD, Falk H, Gibbons S, Kobayashi J, Asakawa Y, Liu JK, eds. Progress in the Chemistry of Organic Natural Products, vol. 107. Cham: Springer International; 2018: 1-94

[21] Zhang DM, Xu HG, Wang L, Li Y], Sun PH, Wu XM, Wang G], Chen WM, Ye WC. Betulinic acid and its derivatives as potential antitumor agents. Med Res Rev 2015; 35: 1127-1155

[22] Ali-Seyed M, Jantan I, Vijayaraghavan K, Bukhari SNA. Betulinic acid: Recent advances in chemical modifications, effective delivery, and molecular mechanisms of a promising anticancer therapy. Chem Biol Drug Des 2016; 87: 517-536

[23] Pettit GR, Melody N, Hempelstall F, Chapuis JC, Groy TL, Williams L. Antineoplastic agents. 595. Structural modifications of betulin and the X-ray crystal structure of an unusual betulin amine dimer. J Nat Prod 2014; 77: 863-872

[24] Ye Y, Zhang T, Yuan H, Li D, Lou H, Fan P. Mitochondria-targeted lupane triterpenoid derivatives and their selective apoptosis-inducing anticancer mechanisms. J Med Chem 2017; 60: 6353-6363

[25] Kim DSHL, Pezzuto JM, Pisha E. Synthesis of betulinic acid derivatives with activity against human melanoma. Bioorg Med Chem Lett 1998; 8: $1707-1712$

[26] Tsepaeva OV, Nemtarev AV, Abdullin TI, Grigor'eva LR, Kuznetsova EV, Akhmadishina RA, Ziganshina LE, Cong HH, Mironov VF. Design, synthesis, and cancer cell growth inhibitory activity of triphenylphosphonium derivatives of the triterpenoid betulin. J Nat Prod 2017; 80: 2232-2239

[27] Pettit GR, Melody N, Chapuis JC. Antineoplastic agents. 606. The betulastatins. J Nat Prod 2018; 81: 458-464 
[28] Seneja A, Sharma L, Dubey RD, Mintoo M], Singh A, Kumar A, Sangwan PL, Tasaduq SA, Singh G, Mondhe DM, Gupta PN. Synthesis, characterization and augmented anticancer potential of PEG-betulinic acid conjugate. Mat Sci Eng C 2017; 73: 616-626

[29] Shanmugam MK, Dai X, Kumar AP, Tan BKH, Sethi G, Bishayee A. Oleanolic acid and its synthetic derivatives for the prevention and therapy of cancer: preclinical and clinical evidence. Cancer Lett 2014; 346: 206216

[30] Lúcio KA, Rocha GG, Moncão-Ribeiro LC, Fernandes ], Takiya CM, Gattass CR. Oleanolic acid initiates apoptosis in non-small cell lung cancer cell lines and reduces metastatis of a B16F10 melanoma model in vivo. PLoS One 2011; 6: e28596

[31] Li HF, Wang XA, Xiang SS, Hu YP, jiang L, Shu YJ, Li ML, Wu XS, Zhang F, Ye YY, Weng H, Bao RF, Cao Y, Lu W, Dong Q, Liu YB. Oleanolic acid induces mitochondrial-dependent apoptosis and G0/G1 phase arrest in gallbladder cancer cells. Drug Des Dev Ther 2015; 9: 3017-3030

[32] Takemura M, Endo S, Matsunaga T, Soda M, Zhao HT, El-Kabbani O, Tajima K, linuma M, Hara A. Selective inhibition of the tumor marker aldo-keto reductase family member $1 \mathrm{~B} 10$ by oleanolic acid. J Nat Prod 2011; 74: 1201-1206

[33] Shi Y, Song Q, Hu D, Zhuang X, Yu S, Teng D. Oleanolic acid induced autophagic cell death in hepatocellular carcinoma cells via PI3K/Akt/mTOR and ROS-dependent pathway. Korean J Physiol Pharmacol 2016; 20: 237-243

[34] Bernabé-García Á, Armero-Barranco D, Liarte S, Ruzafa-Martínez M, Ramos-Morcillo AJ, Nicolás FJ. Oleanolic acid induces migration in Mv1Lu and MDA-MB-231 epithelial cells involving EGF receptor and MAP kinases activation. PLoS One 2017; 12: e0172574

[35] Xu Y, Shu B, Tian Y, Wang G, Wang Y, Wang J, Dong Y. Oleanolic acid induces osteosarcoma cell apoptosis by inhibition of Notch signaling. Mol Carcinog 2018; 57: 896-902

[36] Luo Y, Liu Z, Zhang X, Huang J, Yu X, Li J, Xiong D, Sun X, Zhong Z. Effect of a controlled-release drug delivery system made of oleanolic acid formulated into multivesicular liposomes on hepatocellular carcinoma in vitro and in vivo. Int J Nanomed 2016; 11: 3111-3129

[37] Honda T, Rounds BV, Bore L, Finlay HJ, Favaloro FG, Suh N, Wang Y, Sporn MB, Gribble GW. Synthetic oleanane and ursane triterpenoids with modified rings $A$ and $C$ : A series of highly active inhibitors of nitric oxide production in mouse macrophages. J Med Chem 2000; 43: 4233-4246

[38] Wang TT, Liu Y, Chen L. Synthesis and cytotoxic activity of nitric oxidereleasing isosteviol derivatives. Bioorg Med Chem Lett 2014; 24: 22022205

[39] Ball MS, Shipman EP, Kim H, Liby KT, Pioli PA. CDDO-Me redirects activation of breast tumor associated macrophages. PLoS One 2016; 11: e0149600

[40] Wang YY, Zhe H, Zhao R. Preclinical evidences toward the use of triterpenoid CDDO-Me for solid cancer prevention and treatment. Mol Cancer 2014; 13: 30

[41] Gao X, Deeb D, Liu Y, Liu P, Zhang Y, Shaw J, Gautam SC. CDDO-Me inhibits tumor growth and prevents recurrence of pancreatic ductal adenocarcinoma. Int J Oncol 2015; 47: 2100-2106

[42] Nagaraj S, Youn JI, Weber H, Iclozan C, Lu L, Cotter M], Meyer C, Becerra $\mathrm{CR}$, Fishman M, Antonia S, Sporn MB, Liby $\mathrm{KT}$, Rawal B, Lee $\mathrm{H}$, Gabrilovich DI. Anti-inflammatory triterpenoid blocks immune suppressive function of MDSCs and improves immune response in cancer. Clin Cancer Res 2010; 16: 1812-1823

[43] Wang YY, Yang YX, Zhe H, He ZX, Zhou SF. Bardoxolone methyl (CDDO-Me) as a therapeutic agent: An update on its pharmacokinetic and pharmacodynamic properties. Drug Des Dev Ther 2014; 8: 20752088

[44] Cragg GM, Grothaus PG, Newman DJ. New horizons for old drugs and drug leads. J Nat Prod 2014; 77: 703-723
[45] Schmid C, Dawid C, Peters V, Hofmann T. Saponins from European licorice roots (Glycyrrhiza glabra). J Nat Prod 2018; 81: 1734-1744

[46] Li K, Ji S, Song W, Kuang Y, Lin Y, Tang S, Cui Z, Qiao X, Yu S, Ye M. Glycybridins A-K, bioactive phenolic compounds from Glycyrrhiza glabra. J Nat Prod 2017; 80: 334-346

[47] Zhang X, Yang H, Yue S, He G, Qu S, Zhang Z, Ma B, Ding R, Peng W, Zhang $\mathrm{H}$, Yang Z, Dou K, Tao K, Li X. The mTOR inhibition in concurrence with ERK1/2 activation is involved in excessive autophagy induced by glycyrrhizin in hepatocellular carcinoma. Cancer Med 2017; 6: 1941-1951

[48] Liu SH, Cheng YC. Old formula, new $R_{\mathrm{x}}$ : the journey of PHY906 as cancer adjuvant therapy. J Ethnopharmacol 2012; 140: 614-623

[49] Kummar S, Copur MS, Rose M, Wadler S, Stephenson J, O'Rourke M, Brenckman W, Tilton R, Liu SH, Jiang Z, Su T, Cheng YC, Chu E. A phase I study of the Chinese herbal medicine PHY906 as a modulator of irinotecan-based chemotherapy in patients with advanced colorectal cancer. Clin Colorect Cancer 2011; 10: 85-96

[50] Saif MW, Li ], Lamb L, Kaley K, Elligers K, Jiang Z, Bussom S, Liu SH, Cheng YC. First-in-human phase II trial of the botanical formulation PHY906 with capecitabine as second-line therapy in patients with advanced pancreatic cancer. Cancer Chemother Pharmacol 2014; 73: 373-380

[51] Ren Y, VanSchoiack A, Chai HB, Goetz M, Kinghorn AD. Cytotoxic barrigenol-like triterpenoids from an extract of Cyrilla racemiflora housed in a repository. J Nat Prod 2015; 78: 2440-2446

[52] Jiao Q, Zou L, Liu P, Xu Q, Zhang Y, Yu Y, Zou L, Chi T, Ji X. Xanthoceraside induces apoptosis in melanoma cells through the activation of caspases and the suppression of the IGF-1R/Raf/MEK/ERK signaling pathway. J Med Food 2014; 17: 1070-1078

[53] Shanmugam MK, Rajendran P, Li F, Nema T, Vali S, Abbasi T, Kapoor S, Sharma A, Kumar AP, Ho PC, Hui KM, Sethi G. Ursolic acid inhibits multiple cell survival pathways leading to suppression of growth of prostate cancer xenograft in nude mice. J Mol Med 2011; 89: 713-727

[54] Yang L, Liu X, Lu Z, Chan JYW, Zhou L, Fung KP, Wu P, Wu S. Ursolic acid induces doxorubicin-resistant HepG2 cell death via the release of apoptosis-inducing factor. Cancer Lett 2010; 298: 128-138

[55] Zhang J, Wang W, Qian L, Zhang Q, Lai D, Qi C. Ursolic acid inhibits the proliferation of human ovarian cancer stem-like cells through epithelialmesenchymal transition. Oncology Rep 2015; 34: 2375-2384

[56] Ren Y, Anaya-Eugenio GD, Czarnecki AA, Ninh TN, Yuan C, Chai HB, Soejarto DD, Burdette JE, Carcache de Blanco EJ, Kinghorn AD. Cytotoxic and NF- $\kappa B$ and mitochondrial transmembrane potential inhibitory pentacyclic triterpenoids from Syzygium corticosum and their semi-synthetic derivatives. Bioorg Med Chem 2018; 26: 4452-4460

[57] Hata K, Hori K, Takahashi S. Differentiation- and apoptosis-inducing activities by pentacyclic triterpenes on a mouse melanoma cell line. J Nat Prod 2002; 65: 645-648

[58] Tian T, Liu X, Lee ES, Sun J, Feng Z, Zhao L, Zhao C. Synthesis of nove oleanolic acid and ursolic acid in C-28 position derivatives as potential anticancer agents. Arch Pharm Res 2017; 40: 458-468

[59] Sun L, Li B, Su X, Chen G, Li Y, Yu L, Li L, Wei W. An ursolic acid derived small molecule triggers cancer cell death through hyperstimulation of macropinocytosis. J Med Chem 2017; 60: 6638-6648

[60] Fan L, Zhang B, Xu A, Shen Z, Guo Y, Zhao R, Yao H, Shao JW. Carrierfree, pure nanodrug formed by the self-assembly of an anticancer drug for cancer immune therapy. Mol Pharm 2018; 15: 2466-2478

[61] Shishodia S, Majumdar S, Banerjee S, Aggarwal BB. Ursolic acid inhibits nuclear factor- $\kappa B$ activation induced by carcinogenic agents through suppression of $\mathrm{I} \mathrm{B} \alpha$ kinase and p65 phosphorylation: correlation with down-regulation of cyclooxygenase 2, matrix metalloproteinase 9 , and cyclin D1. Cancer Res 2003; 63: 4375-4383

[62] Qian Z, Wang X, Song Z, Zhang H, Zhou S, Zhao ], Wang H. A phase I trial to evaluate the multiple-dose safety and antitumor activity of ursolic acid liposomes in subjects with advanced solid tumors. Biomed Res Int 2015; 2015: 809714 
[63] Chen JC, Chiu MH, Nie RL, Cordell GA, Qiu SX. Cucurbitacins and cucurbitane glycosides: structures and biological activities. Nat Prod Rep 2005; 22: 386-399

[64] Lee DH, Iwanski GB, Thoennissen NH. Cucurbitacin: Ancient compound shedding new light on cancer treatment. ScientificWorldjournal 2010; 10: 413-418

[65] Ríos JL, Andúlar I, Escandell JM, Giner RM, Recio MC. Cucurbitacins as inducers of cell death and a rich source of potential anticancer compounds. Curr Pharm Des 2012; 18: 1663-1676

[66] Pan L, Yong Y, Deng Y, Lantvit DD, Ninh TN, Chai H, Carcache de Blanco EJ, Soejarto DD, Swanson SM, Kinghorn AD. Isolation, structure elucidation, and biological evaluation of 16,23-epoxycucurbitacin constituents from Elaeocarpus chinensis. J Nat Prod 2012; 75: 444-452

[67] Abbas S, Vincourt JB, Habib L, Netter P, Greige-Gerges H, Magdalou J. The cucurbitacins E, D and I: Investigation of their cytotoxicity toward human chondrosarcoma SW 1353 cell line and their biotransformation in human liver. Toxicol Lett 2013; 216: 189-199

[68] Fang X, Phoebe CH, Pezzuto JM, Fong HHS, Farnsworth NR, Yellin B, Hecht SM. Plant anticancer agents. XXXIV. Cucurbitacins from Elaeocarpus dolichostylus. J Nat Prod 1984; 47: 988-993

[69] Kim DK, Choi SH, Lee JO, Ryu SY, Park DK, Shin DH, Jung JH, Pyo SK, Lee KR, Zee OP. Cytotoxic constituents of Sorbaria sorbifolia var. stellipila. Arch Pharm Res 1997; 20: 85-87

[70] Takahashi N, Yoshida Y, Sugiura T, Matsuno K, Fujino A, Yamashita U. Cucurbitacin D isolated from Trichosanthes kirilowii induces apoptosis in human hepatocellular carcinoma cells in vitro. Int Immunopharmacol 2009; 9: 508-513

[71] Spear SA, Burns SS, Oblinger JL, Ren Y, Pan L, Kinghorn AD, Welling DB Chang LS. Natural compounds as potential treatments of NF2-deficient schwannoma and meningioma: cucurbitacin D and goyazensolide. Otol Neurotol 2013; 34: 1519-1527

[72] Ku JM, Kim SR, Hong SH, Choi HS, Seo HS, Shin YC, Ko SG. Cucurbitacin D induces cell cycle arrest and apoptosis by inhibiting STAT3 and NF- $K B$ signaling in doxorubicin-resistant human breast carcinoma (MCF7/ADR) cells. Mol Cell Biochem 2015; 409: 33-43

[73] Nakanishi T, Song Y, He C, Wang D, Morita K, Tsukada J, Kanazawa T, Yoshida Y. Autophagy is associated with cucurbitacin D-induced apoptosis in human T cell leukemia cells. Med Oncol 2016; 33: 30

[74] Hall JA, Seedarala S, Rice N, Kopel L, Halaweish F, Blagg BS]. Cucurbitacin D is a disruptor of the HSP90 chaperone machinery. J Nat Prod 2015; 78: 873-879

[75] Sikander M, Hafeez BB, Malik S, Alsayari A, Halaweish FT, Yallapu MM, Chauhan SC, Jaggi M. Cucurbitacin D exhibits potent anti-cancer activity in cervical cancer. Sci Rep 2016; 6: 36594

[76] Ruan J, Zheng C, Qu L, Liu Y, Han L, Yu H, Zhang Y, Wang T. Plant resources, ${ }^{13} \mathrm{C}$-NMR spectral characteristic and pharmacological activities of dammarane-type triterpenoids. Molecules 2016; 21: 1047

[77] Patel S, Rauf A. Adaptogenic herb ginseng (Panax) as medical food: Status quo and future prospects. Biomed Pharmacother 2017; 85: 120-127

[78] Chen XJ, Zhang XJ, Shui YM, Wan JB, Gao JL. Anticancer activities of protopanaxadiol- and protopanaxatriol-type ginsenosides and their metabolites. Evid Based Compl Altern Med 2016; 2016: 5738694

[79] Wang W, Zhao Y, Rayburn ER, Hill DL, Wang H, Zhang R. In vitro anticancer activity and structure-activity relationships of natural products isolated from fruits of Panax ginseng. Cancer Chemother Pharmacol 2007; 59: 589-601

[80] Kwak JH, Park JY, Lee D, Kwak JY, Park EH, Kim KH, Park HJ, Kim HY, Jang HJ, Ham J, Hwang GS, Yamabe N, Kang KS. Inhibitory effects of ginseng sapogenins on the proliferation of triple negative breast cancer MDA-MB-231 cells. Bioorg Med Chem Lett 2014; 24: 5409-5412

[81] Liu GY, Bu X, Yan H, Jia WWG. 20S-Protopanaxadiol-induced programmed cell death in glioma cells through caspase-dependent and -independent pathways. J Nat Prod 2007; 70: 259-264
[82] Teng B, Jiang J, Zhao L, Gao J, Chen J, Liu Z, Wang H, Lu B. Ginsenoside PPD's antitumor effect via down-regulation of mTOR revealed by superresolution imaging. Molecules 2017; 22: 486

[83] Teng B, Zhao L, Gao J, He P, Li H, Chen J, Feng Q, Yi C. 20(S)-Protopanaxadiol (PPD) increases the radiotherapy sensitivity of laryngeal carcinoma. Food Funct 2017; 8: 4469-4477

[84] Zhang Z, Li Z, Wu X, Zhang CF, Calway T, He TC, Du W, Chen J, Wang CZ, Yuan CS. TRAIL pathway is associated with inhibition of colon cancer by protopanaxadiol. J Pharmacol Sci 2015; 127: 83-91

[85] Wang CZ, Zhang Z, Wan JY, Zhang CF, Anderson S, He X, Yu C, He TC, Qi LW, Yuan CS. Protopanaxadiol, an active ginseng metabolite, significantly enhances the effects of fluorouracil on colon cancer. Nutrients 2015; 7: 799-814

[86] Cao B, Qi Y, Yang Y, Liu X, Xu D, Guo W, Zhan Y, Xiong Z, Zhang A, Wang AR, Fu X, Zhang H, Zhao L, Gu J, Dong Y. 20(S)-Protopanaxadiol inhibition of progression and growth of castration-resistant prostate cancer. PLoS One 2014; 9: e111201

[87] Zhang B, Zhou WJ, Gu C], Wu K, Yang HL, Mei J, Yu JJ, Hou XF, Sun JS, Xu FY, Li DJ, Jin LP, Li MQ. The ginsenoside PPD exerts anti-endometriosis effects by suppressing estrogen receptor-mediated inhibition of endometrial stromal cell autophagy and NK cell cytotoxicity. Cell Death Dis 2018; 9: 574

[88] Han M, Ma L, Yu X, Li Z, Guo Y, Wang X. A nanoparticulate drug-delivery system for 20(S)-protopanaxadiol: formulation, characterization, increased oral bioavailability and anti-tumor efficacy. Drug Deliv 2016; 23: $2410-2418$

[89] Hao M, Wang W, Zhao Y, Zhang R, Wang H. Pharmacokinetics and tissue distribution of 25-hydroxyprotopanaxadiol, an anti-cancer compound isolated from Panax ginseng, in athymic mice bearing xenografts of human pancreatic tumors. Eur J Drug Metab Pharmacokinet 2011; 35: 109-113

[90] Bi X, Zhao Y, Fang W, Yang W. Anticancer activity of Panax notoginseng extract 20(S)-25-OCH $\mathrm{OCH}_{3}$-PP: Targeting $\beta$-catenin signaling. Clin Exp Pharmacol Physiol 2009; 36: 1074-1078

[91] Wu YL, Wan Y, Jin XJ, OuYang BQ, Bai T, Zhao YQ, Nan JX. 25-OCH - PPD induces the apoptosis of activated $\mathrm{t}-\mathrm{HSC} / \mathrm{Cl}-6$ cells via c-FLIP-mediated NF-KB activation. Chem Biol Interact 2011; 194: 106-112

[92] Zhao C, Su G, Wang X, Zhang X, Guo S, Zhao Y. Antitumor activity of ginseng sapogenins, 25-OH-PPD and $25-\mathrm{OCH}_{3}-\mathrm{PPD}$, on gastric cancer cells. Biotechnol Lett 2016; 38: 43-50

[93] Wang W, Rayburn ER, Zhao Y, Wang H, Zhang R. Novel ginsenosides 25$\mathrm{OH}-\mathrm{PPD}$ and $25-\mathrm{OCH}_{3}$-PPD as experimental therapy for pancreatic cancer: Anticancer activity and mechanisms of action. Cancer Lett 2009; 278: $241-248$

[94] Li W, Zhang X, Xin Y, Xuan Y, Liu J, Li P, Zhao Y. Oral subchronic toxicity evaluation of a novel antitumor agent 25-methoxydammarane-3,12, 20 triol from Panax notoginseng in Sprague-Dawley rats. Regul Toxicol Pharmacol 2016; 77: 240-251

[95] Zhou WX, Sun YY, Yuan WH, Zhao YQ. Water-soluble derivatives of 25$\mathrm{OCH}_{3}$-PPD and their anti-proliferative activities. Steroids 2017; 121: 3239

[96] Loizzo MR, Menichini F, Tundis R. Recent Insights into the Emerging Role of Triterpenoids in Cancer Therapy: Part I. In: Atta-ur-Rahman, ed. Studies in Natural Products Chemistry, Vol. 40. Amsterdam: Elsevier; 2013: 1-31

[97] Tung NH, Song GY, Van Minh C, Van Kiem P, Jin LG, Boo HJ, Kang HK, Kim $\mathrm{YH}$. Steamed ginseng-leaf components enhance cytotoxic effects on human leukemia HL-60 cells. Chem Pharm Bull 2010; 58: 1111-1115

[98] Kim JH, Kim M, Yun SM, Lee S, No JH, Suh DH, Kim K, Kim YB. Ginsenoside Rh2 induces apoptosis and inhibits epithelial-mesenchymal transition in HEC1A and Ishikawa endometrial cancer cells. Biomed Pharmacother 2017; 96: 871-876 
[99] Li KF, Kang CM, Yin XF, Li HX, Chen ZY, Li Y, Zhang Q, Qiu YR. Ginsenoside Rh2 inhibits human A172 glioma cell proliferation and induces cell cycle arrest status via modulating Akt signaling pathway. Mol Med Rep 2018; 17: 3062-3068

[100] Ge G, Yan Y, Cai H. Ginsenoside Rh2 inhibited proliferation by inducing ROS mediated ER stress dependent apoptosis in lung cancer cells. Biol Pharm Bull 2017; 40: 2117-2124

[101] Chen Y, Liu ZH, Xia J, Li XP, Li KQ, Xiong W, Li J, Chen DL. 20(S)-ginsenoside Rh2 inhibits the proliferation and induces the apoptosis of KG-1a cells through the Wnt/ $\beta$-catenin signaling pathway. Oncol Rep 2016; 36: $137-146$

[102] Lv Q, Rong N, Liu L], Xu XL, Liu JT, Jin FX, Wang CM. Antitumoral activity of (20R)- and (20S)-ginsenoside Rh2 on transplanted hepatocellular carcinoma in mice. Planta Med 2016; 82: 705-711

[103] Chen F, Sun Y, Zheng SL, Qin Y, McClements DJ, Hu JN, Deng ZY. Antitumor and immunomodulatory effects of ginsenoside Rh2 and its octyl ester derivative in $\mathrm{H} 22$ tumor-bearing mice. J Funct Foods 2017; 32: 382-390

[104] Li Q, Li B, Dong C, Wang Y, Li Q. 20(S)-Ginsenoside Rh2 suppresses proliferation and migration of hepatocellular carcinoma cells by targeting EZH2 to regulate CDKN2A-2B gene cluster transcription. Eur J Pharmacol 2017; 815: 173-180

[105] Wang YS, Lin Y, Li H, Li Y, Song Z, Jin YH. The identification of molecular target of (20S)-ginsenoside Rh2 for its anti-cancer activity. Sci Rep 2017; 7: 12408

[106] Wang M, Yan S], Zhang HT, Li N, Liu T, Zhang YL, Li XX, Ma Q, Qiu XC, Fan QY, Ma BA. Ginsenoside Rh2 enhances the antitumor immunological response of a melanoma mice model. Oncol Lett 2017; 13: 681685
[107] Achenbach H, Asunka SA, Weibel R, Addae-Mensah I, Oppong IV. Dichapetalin A, a novel plant constituent from Dichapetalum madagascariense with potential antineoplastic activity. Nat Prod Lett 1995; 7 : 93-100

[108] Tuchinda P, Kornsakulkarn J, Pohmakotr M, Kongsaeree P, Prabpai S, Yoosook C, Kasisit J, Napaswad C, Sophasan S, Reutrakul V. Dichapetalin-type triterpenoids and lignans from the aerial parts of Phyllanthus acutissima. J Nat Prod 2008; 71: 655-663

[109] Fang L, Ito A, Chai HB, Mi Q, Jones WP, Madulid DR, Oliveros MB, Gao Q, Orjala J, Farnsworth NR, Soejarto DD, Cordell GA, Swanson SM, Pezzuto JM, Kinghorn AD. Cytotoxic constituents from the stem bark of Dichapetalum gelonioides collected in the Philippines. J Nat Prod 2006; 69: 332-337

[110] Ren Y, Yuan C, Deng Y, Kanagasabai R, Ninh TN, Tu VT, Chai HB, Soejarto DD, Fuchs JR, Yalowich JC, Yu J, Kinghorn AD. Cytotoxic and natural killer cell stimulatory constituents of Phyllanthus songboiensis. Phytochemistry 2015; 111: 132-140

[111] Shanmugam MK, Dai X, Kumar AP, Tan BKH, Sethi G, Bishayee A. Ursolic acid in cancer prevention and treatment: molecular targets, pharmacokinetics and clinical studies. Biochem Pharmacol 2013; 85: 1579-1587

[112] Safe SH, Prather PL, Brents LK, Chadalapaka G, Jutooru I. Unifying mechanisms of action of the anticancer activities of triterpenoids and synthetic analogs. Anticancer Agents Med Chem 2012; 12: 12111220

[113] Ren Y, Yu J, Kinghorn AD. Development of anticancer agents from plant-derived sesquiterpene lactones. Curr Med Chem 2016; 23: $2397-2420$ 